\title{
PERBEDAAN KONTRASEPSI HORMONAL SUNTIK DMPA DAN PIL KOMBINASI DENGAN PENURUNAN GAIRAH SEKSUAL AKSEPTOR KB DI WILAYAH KERJA PUSKESMAS PEKAUMAN KOTA BANJARMASIN \\ TAHUN 2019
}

Differences In Dmpa Hormonal Contraception and Pil Combinations with Passion Reduction Sexual KB Acceptors in The Work Area Pekauman Pekummas City Banjarmasin In 2019

\author{
Intan Nur Karimah*, Ruslinawati**, M. Fahrin Azhari ${ }^{\star \star *}$ \\ Universitas Muhammadiyah Banjarmasin \\ Fakultas Keperawatan dan IImu Kesehatan \\ Program Studi S.1 Keperawatan \\ Email: nintan400@gmail.com
}

\begin{abstract}
ABSTRAK
Kontrasepsi hormonal DMPA dan Pil mengandung hormon estrogen dan progesteron yang memiliki efek samping jika terjadi ketidakseimbangan antara kedua hormon tersebut dapat menyebabkan perubahan aktivitas seksual, karena hormon progesteron menekan hormon estrogen sehingga kekeringan vagina dan menyebabkan perubahan aktivitas seksual. Menganalisa perbedaan penggunaan kontrasepsi hormonal suntik DMPA dan Pil Kombinasi dengan penurunan gairah seksual akseptor KB di wilayah kerja Puskesmas Pekauman Banjarmasin Tahun 2019. Rancangan penelitian kuantitatif, pendekatan cross sectional, populasi 6709 diambil dengan metode purposive sampling sebanyak 100 orang, data dianalisis menggunakan uji Mann Whitney. Hasil menunjukkan akseptor KB jenis kontrasepsi suntik dan pil, 42 orang, akseptor suntik DMPA mengalami penurunan gairah seksual, 41 orang, pil kombinasi mengalami penurunan gairah seksual, tidak terdapat perbedaan akseptor suntik DMPA dan pil kombinasi dengan penurunan gairah seksual pada akseptor KB di Wilayah Kerja Puskesmas Pekauman Kota Banjarmasin Tahun 2019.

Kata Kunci : Gairah Seksual, Kotrasepsi Hormonal DMPA, pil kombinasi
\end{abstract}

\begin{abstract}
Hormonal contraception DMPA and pills contain the hormones estrogen and progesterone which have side effects if an imbalance between the two hormones can cause changes in sexual activity, because the hormone progesterone suppresses the hormone estrogen so that vaginal dryness and causes changes in sexual activity. Analyzing the differences in the use of injectable hormonal contraceptives DMPA and Combination Pills with a decrease in sexual desire KB acceptors in the working area of Banjarmasin Pekauman Health Center in 2019. Quantitative research design, cross sectional approach, population of 6709 taken with a purposive sampling method of 100 people, data were analyzed using the Mann Whitney test. The results showed that contraceptive injectors and pill contraception acceptors, 42 people, DMPA injection acceptors decreased sexual desire, 41 people, combined pill decreased sexual desire, there was no difference in DMPA injection acceptors and combination pills with a decrease in sexual desire in family planning acceptors in the Work Area Pekauman Health Center, Banjarmasin City in 2019. Keywords: Sexual arousal, DMPA hormonal contraception, combination pills
\end{abstract}


Kontrasepsi hormonal banyak memiliki efek Kontrasepsi merupakan salah satu metode untuksamping, salah satunya adalah penurunan mencapai tujuan dari program Badanaktiivitas seksual. Kependudukan dan Keluarga Berencana Nasional (BKKBN). Kontrasepsi digunakan untukAda beberapa faktor yang mempengaruhi mengatur kelahiran anak, jarak, usia ideal, danaktivitas seksual yaitu kurang percaya diri, mengatur kehamilan, jenis kontrasepsi yangtrauma, stres atau depresi, cemas atau gelisah, telah banyak beredar seperti Intra Uterine diet tidak sehat pre mentruasi syndrome (PMS) Device ( IUD), implant, kondom, suntik, Metodedan alat kontrasepsi (Darmodho \& Herdiana Operatif Wanita (WOW), Metode Operatif Pria2007) Dan kedua jenis kontrasepsi tersebut juga (MOP), dan kontrasepsi pil.

mengandung hormone progesterone dan Kontrasepsi hormonal ini memiliki efek samping,estrogen yang apabila digunakan memiliki efek salah satunya terjadi apabila adasamping bagi wanita. Ada beberapa efek ketidakseimbangan antara hormon estrogen dansamping dari kotrasepsi hormonal yaitu sakit progesteron yang dapat menyebabkankepala, perubahan mood, pendarahan tidak perubahan pada aktivitas seksual. Hal initeratur, amenore, perubahan libido. (Everett, dikarenakan hormon progesteron yang2007).

terkandung dalam kontrasepsi hormonal memiliki

efek kerja yang dapat menekan hormon estrogenDisfungsi seksual merupakan adanya gangguan sehingga mengakibatkan vagina menjadi keringpada salah satu atau lebih aspek fungsi seksual dan dapat mengurangi sirkulasi androgen serta(Adams Pangkahila, 2015). Di dalam Fungsi melemahkan peredaran testosteron yangseksual yang dinilai diantaranya adalah gairah memang diperlukan untuk memicu keinginanseksual/libido, orgasme, kepuasan, dan rasa gairah seksual (Semararatih, 2009).

sakit. Penurunan libido adalah akibat efek dari hipoestrogen pada penggunaan KB suntik DMPA Menurut penilitian terdahulu yang dilakukanyang dapat menurunkan frekuensi hubungan (Agustina dkk 2012) didapatkan hasil adaseksual seseorang dan menyebabkan terjadinya pengaruh penggunaan suntik DMPA terhadappenurunan kualitas seksual seseorang. kejadian disfungsi seksual pada akseptor KB,Pemakaian KB suntik DMPA dalam jangka yang dan menurut penelitian yang dilakukan (Herlina,lama dapat menurunkan kadar estrogen dan Kuni 2016) ada hubungan lama pemakaian KBmempengaruhi metabolisme hormon dalam suntik DMPA dengan penurunan libido akseptortubuh serta semakin banyak terjadi efek samping KB di Desa Gondowang, Kecamatan Sawarang,(Damailia \& Saadati, 2016).

Kabupaten Magelang. Dari penelitian tersebut

dapat disimpulkan adanya hubunganPil KB kombinasi mengandung estrogen penggunaan kontrasepsi DMPA denganetinilestradiol (EE) sintetik dan progestin yang penurunan libido/gairah seksual. dapat mempengaruhi kadar serum SHBG dan juga secara potensial dapat mempengaruhi Data dari dokumentasi Puskesmas Pekaumanfungsi seksual wanita (Amra, dkk. 2012). Efek Banjarmasin pada bulan November 2018 untuksamping dari pemakaian KB hormonal pengguna kontrasepsi yaitu sebanyak \%,berhubungan dengan libido seksual yang pada dengan metode yang digunakan pil $32,2 \%$, waktu selanjutnya akan berdampak pada kualitas suntik 56,4\%, implant 7,0\%, kondom 1,1\%,kepuasan seksual bagi pasangan suami istri. MOW (medis operasi wanita) $0,8 \%$, MOP (medisApabila hal tersebut terus berlangsung dalam operasi pria) $0,1 \%$, AKDR 1,5\%.

bahtera rumah tangga maka akan berimbas kepada Kekerasan Dalam Rumah Tangga Dari data diatas dapat diketahui kontrasepsi(KDRT), keharmonisan bahkan perceraian. hormonal jenis suntik dan pil lebih dominan

digunakan dari pada kontrasepsi jenis lain,Studi pendahuluan yang dilakukan pada bulan kedua jenis kontrasepsi tersebut mengalamiFebruari 2019 di wilayah kerja Puskesmas peningkatan, serta penurunan setiap tahunnya.Pekauman Banjarmasin melalui wawancara 
pada 20 orang ibu akseptor KB hormonal suntikSetelah itu peneliti menyiapkan lembar kuesioner DMPA dan pil kombinasi $65 \%$ mengeluhkanyang berisi pertanyaan-pertanyaan tentang bahwa gairah seksualnya menurun.

gairah seksual. Data yang telah dikumpulkan dicek, dikelompokkan dan diberikan skor pada Berdasarkan uraian diatas peniti tertarik untukmasing-masing lembar kuesioner dan melakukan penelitian tentang perbedaanselanjutnya melakukan pengolahan data dan kontrasepsi hormonal suntik DMPA dengan pilanalisa data. Untuk menganalisis perbedaan kombinasi terhadap penurunan gairah seksual dikontrasepsi hormonal suntik DMPA dan pil wilayah kerja Puskesmas Pekaumankombinasi dengan penurunan gairah seksual Banjarmasin. menggunakan kolerasi mann whitney.

\section{Metode Penelitian}

\section{Jenis Penelitian}

Jenis penelitian ini adalah penelitian kuantitatif,DMPA dan pil kombinasi pada pasangan usia dengan desain penelitian komparatif yaitu jenissubur di wilayah kerja Puskesmas Pekauman penelitian yang bersifat membandingkan. Tabel 1 Penggunaan kontrasepsi suntik DMPA dan pil Penelitian ini dilakukan untuk menganalisa perbedaan penggunaan kontrasepsi hormonat. suntik DMPA dan pil kombinasi di wilayah kerjâ. Puskesmas Pekauman Banjarmasin.

\section{Populasi, Sampel, dan Sampling}

Populasi dalam penelitian ini adalah seluruh akseptor KB suntik DMPA dan pil kombinasi di wilayah kerja Puskesmas Pekauman Banjarmasin tahun 2019 sebanyak 6709 akseptor. Sampel dalam penelitian ini sebanyak 100 orang akseptor yang memenuhi kriteria penelitian. Teknik sampling yang digunakan dalam penelitian ini adalah purposive sampling Penelitian ini dilaksanakan di Wilayah Kerja Puskesmas Pekauman Banjarmasin Tahun 2019.No Gairah Seksual Instrumen Penelitian Instrumen yang digunakan dalam penelitian ini adalah kuesioner FSFI yang berisi 19 pertanyaan tentang penurunan gairah seksual, dan 2 pertanyaan tentang kontrasepsi hormonal.

\section{Hasil Penelitian}

\section{Penggunaan kontrasepsi
DMPA dan pil kombinasi pad
subur di wilayah kerja Pusk
Tabel 1 Penggunaan kontraseps
Kombinasi}

\begin{tabular}{llll} 
No. Jenis Kontrasepsi & Frekuensi & Presentase \\
\hline auntik & Sul & 4271 & $56,9 \%$ \\
& Jumlah & 2438 & $32,5 \%$ \\
& Jum & 6709 & $100 \%$ \\
\hline
\end{tabular}

Berdasarkan table 1 dapat dilihat bahwa terdapat 6709 akseptor KB suntik dan pil, dengan pengguna suntik sebanyak 4271 orang $(56,9 \%)$ dan pengguna pil sebanyak 2438 orang $(32,5 \%)$.

Kejadian penurunan gairah seksual pada akseptor suntik DMPA dan pil kombinasi di wilayah kerja Puskesmas Pekauman Banjarmasin pada tahun 2019

Tabel 2 Penurunan Gairah Seksual Suntik DMPA dan Pil Kombinasi

\begin{tabular}{cccc}
\multicolumn{2}{c}{ Suntik } & \multicolumn{3}{c}{ Pil KB } \\
& ase & i & \\
\hline 42 & $84 \%$ & 41 & $82 \%$ \\
8 & $16 \%$ & 9 & $18 \%$ \\
50 & $100 \%$ & 50 & $100 \%$ \\
\hline
\end{tabular}

Prosedur Pengumpulan dan Analisis Data Berdasarkan tabel 2 dapat dilihat bahwa dalam Peneliti mengajukan surat izin penelitian ke penelitian ini lebih dari sebagian akseptor KB bagian fakultas, Setelah mendapatkan surat izin.suntik DMPA dan pil kombinasi mengalami Peneliti menyampaikan surat dari fakultas ke penurunan gairah seksual yaitu kontrasepsi kesbangpol dan dinas kesehatan kotasuntik DMPA sebanyak 42 orang (84\%) dan Banjarmasin untuk melakukan penelitian.sebagian kecil tidak mengalami penurunan Selanjutnya peneliti kemudian memperkenalkan gairah seksual yaitu 8 orang (16\%) dan diri terlebih dahulu kepada responden untuk kontrasepsi pil kombinasi sebanyak 41 orang menjelaskan tujuan, manfaat dan prosedur(82\%) dan sebagian kecil tidak mengalami penelitian serta menyerahkan lembar informed penurunan gairah seksual yaitu 9 orang (18\%).

consent. Kemudian peneliti melakukan pengambilan data akseptor tentang identitas (nama/inisial, alamat, usia, jenis kontrasepsi. 
Perbedaan KB suntik DMPA dan Pil kombinasi Dengan penurunan gairah seksualKejadian penurunan gairah seksual pada di wilayah kerja Puskesmas Pekaumanakseptor suntik DMPA dan pil kombinasi di Banjarmasin 2019

Tabel 3 Perbedaan KB suntik DMPA dan Pil

\begin{tabular}{lccc}
\hline $\begin{array}{l}\text { Kelompok } \\
\text { Responden }\end{array}$ & Mean & $\begin{array}{c}\text { Perbedaan } \\
\text { Mean }\end{array}$ & $\begin{array}{c}\text { Sig (Mann } \\
\text { Whitney=p) }\end{array}$ \\
\hline Suntik & 22,10 & 0,59 & 0,400 \\
Pil Kombinasi & 21,51 & &
\end{tabular}
wilayah kerja Puskesmas Pekauman Banjarmasin pada tahun 2019

Berdasarkan hasil penelitian ini hampir seluruh akseptor mengalami penurunan gairah seksual. Hal tersebut dapat diakibatkan penggunaan kontrasepsi hormonal suntik DMPA yang hanya berisi hormone progesterone yang memiliki efek

Berdasarkan tabel 3 didapatkan hasil bahwa didalam penelitian ini menunjukkan bahwa sebagian besar responden yang menggunakan jenis KB suntik DMPA mengalami penurunan gairah seksual sebanyak 42 orang $(22,10)$. Sedangkan sebagian besar responden yang menggunakan jenis KB pil Kombinasi mengalami penurunan gairah seksual sebanyak 41 orang $(21,51)$. Hasil uji Mann Whitney dengan taraf signifikan $(\alpha)=0,01$ menghasilkan nilai $p$ - value $=0,400$ dan dimana $p>0,01$. Bahwa tidak terdapat perbedaan penurunan gairah seksual antara Akseptor suntik DMPA dan akseptor pil kombinasi diwilayah kerja puskesman pekauman Banjarmasin tahun 2019.

\section{Pembahasan}

Penggunaan kontrasepsi hormonal suntik DMPA dan pil kombinasi pada pasangan usia subur di wilayah kerja Puskesmas Pekauman Banjarmasin tahun 2019

Berdasarkan hasil penelitian ini didapatkan pengguna kontrasepsi hormonal suntik dan pil lebih banyak digunakan dibandingkan jenis kontrasepsi lain. Hal ini dapat dipengaruhi oleh berbagai faktor seperti sosial ekonomi, pendidikan, partisipasi suami/istri, dan juga umur. Sosial ekonomi adalah alah satu faktor yang mempengaruhi pemilihan jenis kontrasepsi dikarenakan setiap penghasilan setiap keluarga berbeda, tinggi rendahnya status sosial ekonomi masyarakat berkaitan erat dengan kemampuan untuk membeli alat kontrasepsi yang digunakan misalnya keluarga berpenghasilan cukup akan lebih mampu mengikuti program KB dari pada keluarga yang tidak mampu. Hal tersebut sejalan dengan penelitian yang dilakukan oleh Anita L dkk (2014) bahwa ada hubungan sosial ekonomi dengan pemilihan jenis kontrasepsi.

Penurunan gairah seksual pada akseptor KB suntik DMPA meskipun jarang terjadi dan tidak dialami pada semua wanita tetapi pada pemakaian lebih dari 2 tahun dapat timbul karena faktor perubahan hormonal, sehingga terjadi pengeringan pada vagina yang menyebabkan nyeri saat bersenggama dan pada akhirnya menurunkan keinginan atau gairah seksual. Keadaan ini merupakan keluhan umum yang disampaikan 1 diantara 10-100 akseptor pengguna DMPA (David, 2012). Terkait nyeri saat berhubungan seksual dari 42 orang responden 31 orang (74\%) mengatakan jika dirinya merasakan kadang-kadang nyeri saat berhubungan seksual, sehingga mengakibatkan keinginan atau gairah seksualnya dalam 4 minggu terakhir menjadi sedang, dalam artian kadang-kadang muncul keinginan dan kadangkadang tidak. dan 11 orang (26\%) mengatakan jika dirinya mengatakan sering merasakan nyeri saat berhubungan seksual, sehingga mengakibatkan keinginan atau gairah seksualnya dalam 4 minggu terakhir menjadi rendah, dalam artian hanya beberapa kali (kurang dari separuh) dalam 4 minggu. Hal ini tidak sejalan dengan penelitian Hanifa, dkk (2018) yang mengatakan variabel dependen nyeri tidak berhubungan signifikan terhadap pemakaian kontrasepsi hormonal suntik. 
tidak terdapat perbedaan yang signifikan Sedangkan untuk pengguna pil kombinasipenurunan gairah seksual akseptor KB suntik hampir seluruh aksepto mengalami penurunanDMPA dan pil kombinasi di Wilayah Kerja gairah seksual. Hal tersebut dikarenakanPuskesmas Pekauman Banjarmasin tahun 2019. kandungan KB pil kombinasi yang mengandung

kedua hormone yaitu estrogen dan progestin,Setiap jenis KB memiliki kelebihan, kelemahan, pada penggunaan kontrasepsi hormonal yangdan efek sampingnya masing-masing namun mengandung kombinasi kedua hormone lebihpada kebanyakan kasus penurunan gairah signifikan dalam menyebabkan disfungsi seksualseksual merupakan efek samping yang dapat dibandingkan dengan kontrasepsi hormonaldijumpai pada setiap penggunaan jenis KB. yang mengandung salah satu hormone (Zahra,Walapun tidak sedikit pula pada penggunaan KB Nisa, 2015). tidak menimbulkan penurunan gairah seksual. Hal ini dikarenakan penurunan gairah seksual Hasil penelitian ini sejalan dengan teori Sujiyatinidapat terbentuk tidak hanya dari penggunaan bahwa efek samping dari kontrasepsi hormonalKB, namun juga ada banyak faktor lain yang dapat menimbulkan kekeringan pada vagina,dapat memberikan pengaruh terhadap perilaku menurunkan libido, gangguan emosi (jarang), dan juga keinginan yang nantinya akan memicu sakit kepala (Sujiyatini, 2009). Terkait kekeringanterjadinya penurunan gairah seksual. Hal ini vagina, dari 41 orang (82\%) akseptor $\mathrm{KB}$ pildapat dilihat dari 100 orang akseptor $\mathrm{KB}$, kombinasi 32 orang (78\%) mengatakan jikasebagian besar akseptor mengalami penurunan selama 4 minggu terakhir ketika berhubungangairah seksual dan sebagian kecil akseptor tidak seksual vaginanya menjadi basah hanyamengalami penurunan gairah seksual atau beberapa kali (kurang dari separuh) selama 4normal. Sehingga pada penggunaan KB suntik minggu. Hal tersebut sejalan dengan penelitianDMPA maupun pil kombinasi, kedua mempunyai Hanifa, dkk (2018) bahwa variabel dependentingkat kemungkinan yang sama terhadap lubrikasi berhubungan seccara signifikan denganterjadinya penurunan gairah seksual.

kelompok pil dan suntuk. Hal tersebut

mengakibatkan akseptor KB merasakan tingkatEfek dari hormon progesterone dalam keinginan atau gairah seksual yang sangatkontrasepsi hormonal berfungsi untuk rendah selama 4 minggu terakhir. Hal ini sejalanmengentalkan lendir serviks dan mengurangi dengan penelitian Hanifa, dkk (2018) yangkemampuan rahim untuk menerima sel yang mengatakan jika variabel dependen hasrattelah dibuahi, sehingga efek sampingnya adalah ternyata berhubungan secara signifikan denganpenurunan aktivitas seksual (Suratun et al., kelompok kontrasepsi implant dan pil.

2008). Hal tersebut mengakibatkan turunnya minat/ gairah seksual akseptor KB hormonal Perbedaan KB suntik DMPA dan Pilsuntik DMPA dan pil kombinasi yang kombinasi Dengan penurunan gairah seksualmengatakan bahwa minat berhubungan seksual di wilayah kerja Puskesmas Pekaumandalam 4 minggu hanya kadang-kadang ada Banjarmasin bahkan hanya beberapa kali. Hasil penelitian ini Perbedaan antara kontrasepsi suntik DMPA dandidukung oleh penelitian Ekaranti di Purworejo pil kombinasi dengan penurunan gairah seksualpada tahun 2006 menunjukkan sebesar 65,6\% dalam penelitian ini yaitu sebanyak 42 orangdari $75 \%$ pengguna KB hormonal mengalami $(22,10 \%)$ akseptor suntik DMPA mengalamihasrat sexual disorder/penurunan libido. Pada penurunan gairah seksual. Sedangkansebuah penelitian lainnya oleh Agus di responden yang menggunakan jenis KB pilTemanggung pada tahun 2010, sebanyak 22 kombinasi, sebagian besar mengalamiorang dari 39 akseptor mengalami penurunan penurunan gairah seksual yaitu sebanyak 41libido setelah selama lebih dari 5 tahun memakai orang $(21,51 \%)$. Berdasarkan hasil analisisKB suntik DMPA.

bivariat menggunakan uji Mann Whitney $p=$

0,400 hal ini menunjukkan bahwa $p>\alpha$ yaituPada penelitian ini, akseptor mengeluh dengan $0,400<0,01$ sehingga dapat disimpulkn bahwaberkurangnya gairah dan merasa malas untuk 
berhubungan seksual sehingga menyebabkan penurunan frekuensi hubungan seksual. Para akseptor juga mengeluh vagina kering saat berhubungan seksual (kurangnya lendir) danImplikasi Hasil Penelitian

merasa nyeri saat berhubungan seksual. Hal iniHasil penelitian ini akan menambah informasi didukung kuat oleh teori Winkjosastro (2009)tentang salah satu efek samping dari menyatakan bahwa DMPA mengandungpenggunaan kontrasepsi hormonal suntik DMPA progesterone yang efek kerjanya adalahdan pil kombinasi pada wanita akseptor KB salah antietrogenik, sehingga penggunaan jangkasatunya yaitu penurunan aktivitas seksual, panjang dapat mengakibatkan defisiensisehingga dapat dijadikan sebagai dasar dalam estrogen sebagian. Efek dari progesteronetindakan keperawatan terutama dalam tindakan sintetik (DMPA) adalah mengurangi sekret,penggunaan kontrasepsi hormonal suntik DMPA peningkatan viskositas dan menurunkandan pil kombinasi.

spinbarkeit. Sedangkan manfaat estrogen sendiriKesimpulan

membantu adanya sekresi pada organResponden yang menggunakan kontrasepsi reproduksi, sehingga hipoestrogen yang terjadisebagian besar menggunakan kontrasepsi pada tubuh wanita dapat menurunkan libido,hormonal suntik DMPA dan pil kombinasi. nyeri saat bersenggama serta terjadinyaResponden yang menggunakan kontrasepsi penurunan densitas tulang. (Baziad,2008). hormonal suntik DMPA dan pil kombinasi sebagian besar mengalami penurunan gairah Faktor psikologi yang menyebabkan penurunanseksual. Tidak terdapat perbedaan yang fungsi dan potensi seksual yaitu kelelahan,signifikan antara penggunaan kontrasepsi kebosanan karena kurang variasi dalamhormonal suntik DMPA dan pil kombinasi dengan kehidupannya, dan disfungsi seksual karenapenuunan gairah seksual di Wilayah Kerja perubahan hormon atau masalah kesehatan jiwaPuskesmas Pekauman Kota Banjarmasin tahun seperti cemas dan depresi. Hal ini dapat2019 memberikan dampak dari perubahan aktivitasDAFTAR RUJUKAN

seksual yaitu akan berpengaruh padaAdams, Pangkahila E, \& Milas, S.F (2015). Pola keharmonisan keberlangsungan hidup Hidup Tidak Teratur dan Aktivitas Fisik berumahtangga (Mardiana, 2011).

\section{Keterbatasan Penelitian} Berlebih Menurunkan Kemampuan Aktivitas Seksual. Sport and Fitness Journal (diakses tanggal 24 Januari 2019)

a. Penelitian ini hanya menghubungkanAnita L, \& Kusmiati, dkk (2014). Faktor -Faktor variabel penggunaan kontrasepsi hormonal Yang Berhubungan Dengan Pemilihan suntik DMPA dan pil kombinasi dengan Kontrasepsi Pasangan Usia Subuh Di aktivitas seksual, yang tidak melakukan Puskesmas Damau Kabupaten Talaud. control terhadap responden sebelum dan JIDAN (Jurnal Ilmiah Bidan). sesudah pemakaian kontrasepsi yang https://ejurnal.poltekkes-manado.ac.id digunakan. (diakses tanggal 29 Juli 2019 jam 21.06).

b. Gairah seksual lebih efektif diteliti denganBaziad, A (2008). Kontrasepsi Hormonal. metode observasi pre dan post akseptor KB menggunakan kontrasepsi hormonal agar terlihat pengaruh dari kontrasepsi tersebut. BKKBN. (2018). Laporan Hasil Pelayanan

c. Penelitian ini tidak menggunakan alat ukur Kontrasepsi (Internet). Tersedia dalam yang sama diwaktu studi pendahuluan dan www.bkkbn.go.id (diakses 20 Januari 2019). penilitian.

Everett, S. (2011). Buku Saku Kontrasepsi Dan

d. Saat pengumpulan data peneliti Kesehatan Seksual Reproduktif. Edisi 2. mendapatkan responden sesuai dengan Jakarta: EGC.

yang dikehendaki tetapi ada responden yangEverett, S. (2008). Buku Saku Kontrasepsi Dan merasa malu dengan pertanyaan yang ada di kuesioner karena pertanyaan bersifat Jakarta: EGC. 
Hanifa, S dkk (2018). Perbandingan Domain Suratun., Maryani, S., Hartini, T., Rusmiati., \& Disfungsi Seksual Pada Wanita Akseptor Pinem, S. (2008). Pelayanan Keluarga Kontrasepsi Hormonal Di Puskesmas Gisting Berencana \& Pelayanan Kontrasepsi. Kabupaten Tanggamus. ( diakses tanggal 15 Jakarta: EGC Juli 2019 jam 20.20).

Tri, Herlina dkk (2016). Hubungan Lama Maryani, H (2008). Cara tepat memilih alat Pemakaian KB Suntik DMPA (Depo kontrasepsi keluarga berencana bagi wanita. Medroxyprogesterone Acetate) Dengan Puslitbang Pelayanan dan Teknologi Kesehatan: Depkes RI. Penurunan Libido Pada Akseptor KB DMPA. Jurnal IImu Kesehatan Bhamada Vol 7 No. 2

Ningsi, Agustina \& Seweng Arifin, dkk (2012). (diakses pada tanggal 24 Januari 2019) Pengaruh Penggunaan Metode KontrasepsiWiknjosastro, Hanifa. (2009). Ilmu Kebidanan. Suntikan DMPA Terhadap Kejadian Jakarta: Yayasan Bina Pustaka Sarwono Disfungsi Seksual. JST Kesehatan Vol 2 No Prawirohardjo.

1. (diakses pada tanggal 24 Januari 2019) Yunardi, dkk (2009). Penggaruh Penyuntikan Semararatih. (2009). Hormon Reproduksi Dosis Minimal Depo Medroxyprogesteron Wanita. Jakarta: Pustaka Mandiri

Sugiyono. (2012). Metode Penelitian Kuantitatif, Kualitatif Dan Kombinasi (Mixced Methods). Bandung: Alfabeta Acetate (DMPA) Terhadap Berat Badan dan Kimia Darah Tikus Galur Spangue-Dawley. Jakarta: Departemen Biologi Kedokteran FK UI. (diakses tanggal 15 Juli 2019 jam 20.25).

Sujarweni, V. W. (2014). Metode Penelitian:Zahra, Z dan Nisa K (2015). Analisis Hubunngan Lengkap Praktis, dan Mudah Dipahami. Yogyakarta: Pustaka Baru Press Penggunaan Kontrasepsi Hormonal dengan Disfungsi Seksual Pada Wanita. (diakses tanggal 4 Juli 2019 jam 08.00 